\title{
Green Secondary Plasticizer/Thermal Stabilizer in PVC Processing
}

\author{
Chất hóa dẻo/ổn định nhiệt thứ cấp thân thiện môi trường trong gia công PVC
}

\author{
Nguyen Thi Thuy*, Vu Minh Duc, Nguyen Thanh Liem \\ School of Chemical Engineering, Hanoi University of Science and Technology, Hanoi, Vietnam \\ Email: thuy.nguyenthi1@hust.edu.vn
}

\begin{abstract}
Replacing 10 php DOP plasticizer by ESO has slightly increased tensile properties of PVC. A variety of media were used to study the leaching property of PVC and the results showed that the presence of ESO as a secondary plasticizer improved the leaching characteristic. There was slight difference in the hardness of the PVC samples with and without the ESO. In general, the PVC material became softer when DOP was partly replaced by ESO. The hardness of both samples became smaller after soaking in water, 30 wt.\% acetic and $10 \mathrm{wt} . \% \mathrm{KOH}$ solution and much bigger in other media. After immersion in n-hexane, the 60/0 sample blistered and became very hard, while the hardness of 50/10 sample increased only $12 \%$. The morphology of fractured surface of the samples after soaking in n-hexane has clearly demonstrated this result. The replacing $10 \mathrm{php}$ DOP by ESO has also improved remarkably migration characteristic, thermal properties, and movement and volatilization in hot air. That means, ESO could be used as a secondary plasticizer/thermal stabilizer in PVC formulation.
\end{abstract}

Keywords: Green plasticizer, epoxidized soybean oil, PVC

Tóm tắt

Thay thế 10 php hóa dẻo DOP bằng ESO đã làm tăng nhẹ các tính chất kéo của PVC. Một loạt các môi trường đã được sử dụng để nghiên cứu đặc trưng chiết tách của PVC và kết quả cho thấy đặc trưng chiết tách đã được cải thiện bởi sự có mặt của ESO. Độ cứng của vật liệu PVC có và không có mặt ESO khác nhau không nhiều. Nhìn chung, vật liệu PVC trở nên mềm hơn khi DOP được thay thế một phần bởi ESO. Độ cứng của các mẫu đều giảm nhẹ sau khi ngâm trong nước, dung dịch acetic $30 \%$ và KOH $10 \%$ nhưng lại tăng rất mạnh trong các môi trường còn lại. Sau khi ngâm trong n-hexane, mẫu 60/0 bị phồng rộp và trở nên rất cứng trong khi độ cứng của mẫu 50/10 chỉ tăng 12\%. Kết quả này còn được khẳng định bởi cấu trúc hình thái bề mặt phá hủy mẫu. Hơn nữa, việc thay thế 10 phần khối lượng DOP bằng ESO cũng cải thiện đáng kể đặc trưng di trú, tính chất nhiệt và đặc trưng di trú và bay hơi trong không khí nóng. Về tổng thể ESO có thể được sử dụng làm chất hóa dẻo/ổn định nhiệt thứ cấp trong đơn PVC.

Từ khóa: PVC, hóa dẻo thân thiện môi trường, dầu đậu nành epoxy hóa

\section{Introduction}

PVC is one of the most widely used thermoplastic in the world [1] and is also known for its hardness, brittleness, and low thermal stability [2]. In order to improve characteristics, additives such as plasticizers and/or thermal stabilizers should be added [3]. There are many types of plasticizers and they can be classified as internal and external [4] or can be either defined as primary and secondary plasticizers [5]. In which, phthalate esters-petroleum based products are the most commonly used plasticizer family $[2,6]$. However, they are well-known to be toxic and will leach from produces into surrounding media [2]. So, they should be replaced with bio-based or renewable environmentally friendly resource $[2,6]$. Epoxidized vegetable oils are suitable candidates because they have many epoxy groups and renewable sources [7]. There are many types of epoxidized oils as linseed oil [8-9], rubber seed oil

ISSN: 2734-9381

https://doi.org/10.51316/jst.149.etsd.2021.31.2.22

Received: September 08,2020; accepted: April 02, 2021
$[10,11]$ that have been used as primary or secondary plasticizers for PVC. Among them, the epoxidized soybean oil is heavily used in PVC processing. Karmalm used an epoxidized soybean oil to form the network in plastisol PVC [12]. In another work of this author, the epoxidized soybean oil was used as primary plasticizer and the thermal stability of PVC was estimated by yellowness index, transmittance and chlorine analyses [13]. The epoxidized soybean oil was also used to improve characteristic and thermal stability of PVC for food packaging [14]. In Vietnam, the epoxidized soybean oil was used as secondary plasticizer in the fabrication of PVC/black coal and fly ash composites [15].

In the presence work, the epoxidized soybean oil was used as green secondary plasticizer/thermal stabilizer in PVC processing. Beside tensile properties, some tests as a leaching, migration, migration and volatilization in hot air were performed to estimate characteristics of PVC. The thermal property of PVC was studied by using TGA analysis. 


\section{Materials and methods}

\subsection{Materials}

The epoxidized soybean oil (ESO) with oxirane content of $6.2 \%$ was purchased from Henan Go Biotech Co., Ltd, China. The PVC TH-1000R was provided by Taiyo Vinyl Corporation, Japan. The heat stabilizer was purchased from Huike, China. The processing aid Metablen 551J was furnished by Mitsubishi Chemical, Japan. The DOP plasticizer, stearic acid 401 and PE wax SCG were of China, Indonesian and Thai origin, respectively.

\subsection{Methods}

The purpose of this study was to replace a part of DOP in the PVC recipe with ESO. Therefore, some PVC materials with different ESO contents were prepared to evaluate the properties and thus to provide the most suitable ESO content for replacing a part of DOP in PVC recipe. The compositions in formulation of PVC materials were presented in Table 1.

Table 1. The compositions in PVC formulation

\begin{tabular}{ccc|}
\hline No & Compositions & Remarks \\
\hline 1 & PVC & 100 \\
2 & DOP & Changeable \\
3 & ESO & Changeable \\
4 & Heat stabilizer & 2 \\
5 & Acid stearic & 0.2 \\
6 & PE wax & 0.5 \\
7 & Procession aid & 3 \\
\hline
\end{tabular}

\subsubsection{List of operations}

The mixer: Firstly, PVC and additives were premixed at $100{ }^{\circ} \mathrm{C}$ in a mixing device at a mixing speed of $2400 \mathrm{rpm}$ for 10 minutes then cooled quickly to $50{ }^{\circ} \mathrm{C}$ and continued to mix for 5 minutes and then incubated at room temperature in 24 hours. Secondly, the Hakke Polylab System Rheomix was used to mix. The mixture was introduced gradually during the first minute. The mixing time and speed were kept constant with a duration of 5 minutes and $50 \mathrm{rpm}$ at temperature of $180{ }^{\circ} \mathrm{C}$. Finally, the PVC-based sample was collected and flattened with a steel roller before being stored in plastic bags at room temperature.

The hot press machine: The PVC-based samples were heated at $200{ }^{\circ} \mathrm{C}$ and pressed at $130 \mathrm{~kg} / \mathrm{cm}^{2}$ by using Gotech model GT-70140-P30C to get thin films of $500 \mu \mathrm{m}$ thickness on average or cylindrical blocks of $8 \mathrm{~cm}$ diameter and $3 \mathrm{~mm}$ thickness.

The manual punch press: Once the films are made, they had to be shaped before testing. A manual punch press was used for this purpose.

\subsubsection{Analytical techniques}

Morphology: Morphologies of samples were studied by using a scanning electron microscope (SEM, JSM-6360/6360LV Japan).

Tensile properties: Tensile strength of samples was determined according to ASTM D638 standard by using Lloyd, England.

Thermal property: The thermal properties were analysed by thermogravimetric analysis (TGA) on a (DTA/DSC/TGA) Labsys Evo S60/58988 (France).

Shore test: The shore A hardness of samples was determined according to ASTM D2240 standard by using Teclock GS 709, Japan.

Leaching test: The leaching of plasticizers from plasticized PVC sample was carried out based on ASTM D 1239-98 standard. The PVC specimens were dipped in media such as distilled water, 30wt.\% acetic acid solution, 10wt.\% potassium hydroxide solution, n-hexane and sunflower oil in 24 hours at $23 \pm 1{ }^{\circ} \mathrm{C}$ and $50 \pm 5 \%$ relative humidity. The extracted PVC specimens were rinsed with flowing water, wiped up and dried in a Memmert convection oven at $40{ }^{\circ} \mathrm{C}$ for 24 hours. The weight of PVC specimens before and after immersed was measured. Three specimens were tested to obtain an average value.

Migration test: The migration of plasticizers from plasticized PVC films to other film as filer paper was investigated at room temperature over a two-week period or $60{ }^{\circ} \mathrm{C}$ for 48 hours in a convection oven. The exudation of the plasticizers was evaluated by placing a rectangular plasticized PVC sheets of $20 \times 50 \mathrm{~mm}^{2}$ surface area and about $500 \mu \mathrm{m}$ thickness between two pieces of filter paper of the same shape. These systems were kept in contact by sandwiching between two glass microscopy slides and binder clips. The weight gain of filter papers and weight loss of plasticized PVC specimens were calculated and the amount of plasticizer that migrated from plasticized PVC specimens to filter papers was averaged from three test specimens.

Migration and volatilization test: The rectangular plasticized PVC sheets of $20 \times 50 \mathrm{~mm}^{2}$ surface area and about $500 \mu \mathrm{m}$ thickness were heated in an air circulating oven at $100^{\circ} \mathrm{C}$ for 8 days. The change of weight was measured after heat treatment. At each specified time, the samples were taken off and weighted. The variation of the mass was evaluated as a function of time.

\section{Results and Discussion}

\subsection{The effect of ESO content on tensile properties}

The tensile properties of PVC are the characteristics that most clearly show the plasticizing effect of both primary and secondary plasticizers. In 
this experiment, the change in the plasticizer content, including both primary and secondary, significantly affected the tensile properties of PVC. The loading of ESO raised and DOP decreased, tensile strength and elongation at break increased and reached to the maximum value at the DOP/ESO ratio of 50/10 and tended to reduce if the ESO content exceeded the point. As can be seen in Fig.1, there was the improvement of 5 and $6 \%$ in tensile strength and elongation at break, respectively.

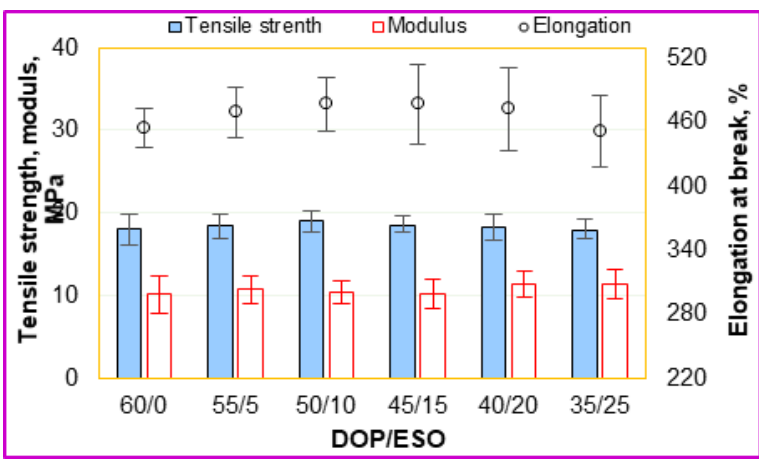

Fig. 1. The effect of ESO content on the mechanical properties of PVC

Like the tensile strength and elongation at break, the presence of ESO also affected the tensile modulus of PVC. However, this effect was more evident when the ESO content was high. An increase of 11.6 or $12 \%$ of the modulus of PVC sample was observed when the DOP/ESO ratio was $40 / 20$ or $35 / 25$.

In general, the plasticizing effect of the secondary plasticizer was most evident when $10 \mathrm{php}$ (parts per hundred polyvinylchloride) of DOP was replaced by ESO in the PVC formulation.

\subsection{The effect of ESO on leaching property}

In addition to plasticizing role, the extraction properties of plasticizer as DOP are also of great interest. In many cases, the extraction of plasticizers like DOP to the environment limits the application of PVC. Epoxidized vegetable oils are considered to be a secondary plasticizer and also have the effect of improving the extraction properties [16]. In this experiment, the leaching test of 60/0 (the PVC using only 60 php DOP) and 50/10 (the PVC using 50 php DOP and 10 php ESO) sample in media was performed and the result was showed in Fig.2.

The increase in weight in media as water and 30 wt.\% acetic solution proved that the process by which the tiny molecules of media penetrated into the samples dominated the process by which additives were extracted from material into the medium. In media like 10 wt.\% potassium hydroxide solution, sunflower oil and n-hexane, the opposite was true due to the reduction of weight after immersing (Fig. 2). The more increase of sample weight in water and 30 wt.\% acetic solution and the less decrease in remaining media indicated the improvement in leaching property by the presence of $10 \mathrm{php}$ ESO. This result is consistent with the results in our published work [17].

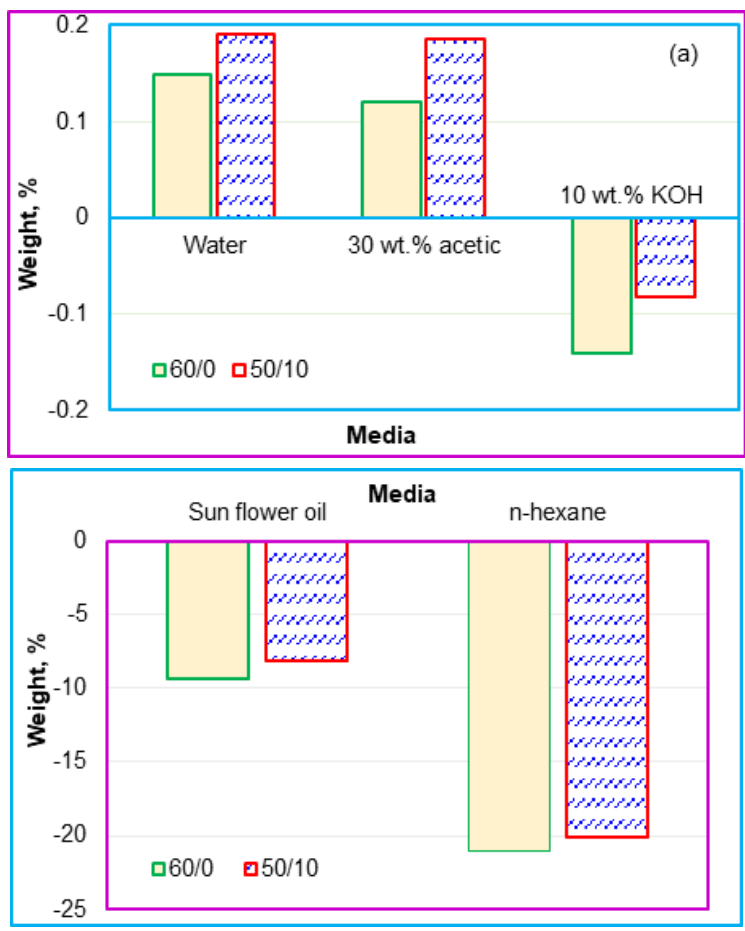

Fig. 2. The effect of ESO on the leaching property of PVC in media: (a) water, acid and base (b) oil and n-hexane

Table 2. The shore A of PVC in media

\begin{tabular}{lcc}
\hline \multirow{2}{*}{ Medium } & \multicolumn{2}{c}{ Shore A } \\
\cline { 2 - 3 } Air & $60 / 0$ & $50 / 10$ \\
Water & 68.5 & 68.3 \\
KOH 10\% & 67.0 & 66.9 \\
Sunflower oil & 65.9 & 65.4 \\
n-hexane & 72.8 & 72.3 \\
\hline
\end{tabular}

Any increase or decrease in the weight of the sample after immersing leads to a change in compositions, which in turn will change the properties of the PVC. The tiny molecules of water or 30 wt.\% acetic solution penetrated into material, interposed the macromolecule chains, making the macromolecule chains more flexible, resulting in less hard materials. Therefore, the shore A hardness of both samples after soaking in these media was slightly lower than that of non-immersing samples (table 2). The additives extracted from the sample will make material harder. Thus, the shore A hardness of both samples after soaking in sunflower and nhexane was bigger than that of non-soaking samples. Especially, after soaking in n-hexane, the hardness of $50 / 10$ sample increased by $12 \%$ while $60 / 0$ sample was blistered and became very hard, exceeding the scale of Teclock GS 709 machine (table 2). This 
result demonstrated the ability to improve the leaching property of PVC when $10 \mathrm{php}$ DOP in formulation was replaced by ESO.

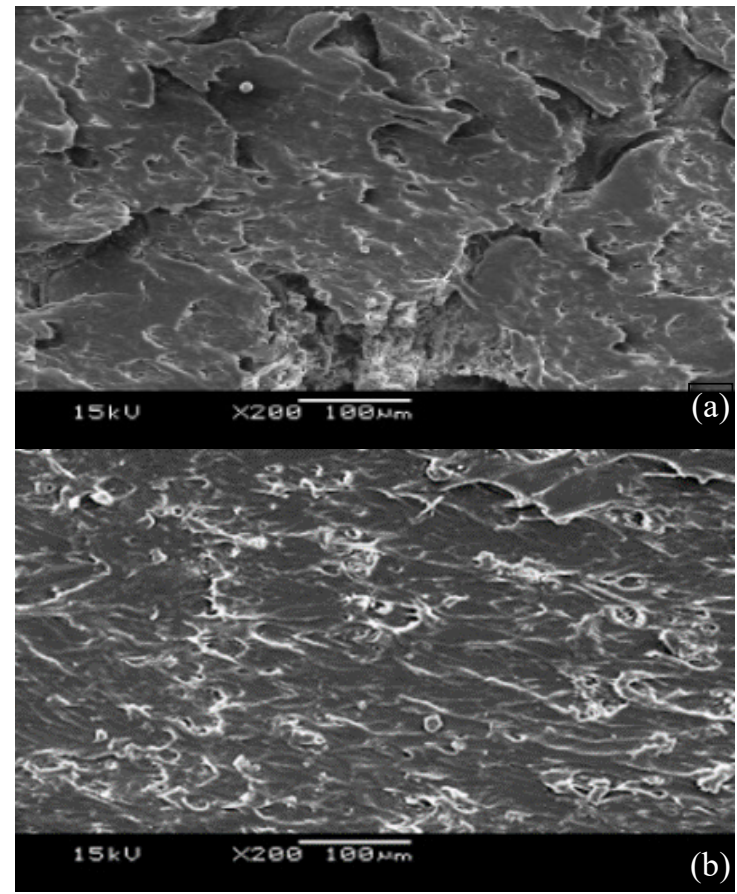

Fig. 3. The SEM of 60/0 (a) and 50/10 (b) samples

At a magnification of 200 , a lot of holes and cracks were observed on the fracture surface of the $60 / 0$ sample (Fig. 3a), but they were very difficult to observe on the fracture surface of the 50/10 sample Fig. 3b). The morphology of fracture surface of both samples once again confirmed the positive role of secondary plasticizer as ESO.

\subsection{The effect of ESO on migration property}

The migration characteristic of plasticizer was estimated in two media. The weight of additive as DOP and ESO moving to the surface after 2 weeks at $25^{\circ} \mathrm{C}$ or 48 hours at $60{ }^{\circ} \mathrm{C}$ of the $50 / 10$ sample was smaller than that of the $60 / 0$ sample (Fig. 4). It demonstrated that the ESO was not only effective in plasticizing PVC (Fig. 1) and improving in leaching property (Fig. 2), but also had a positive effect in reducing the migration of additives to material surface (Fig. 4).

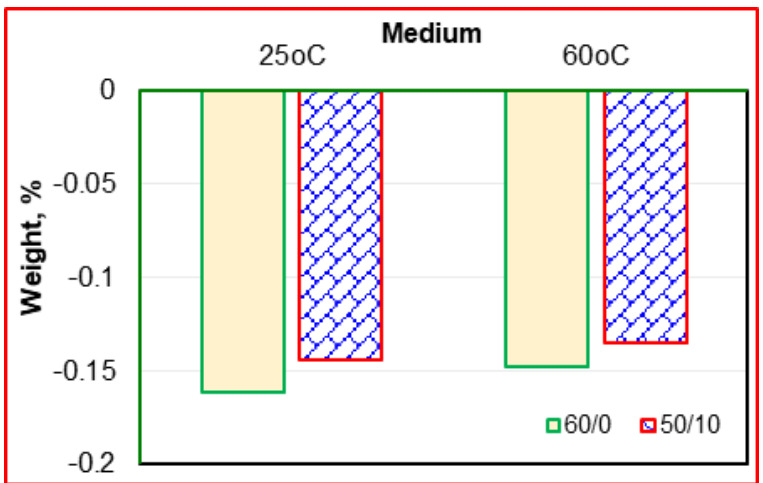

Fig. 4. The effect of ESO on migration property

\subsection{The effect of ESO on migration and volatilization}

The Fig.5 showed that, the loss weight of samples raised over time. The loss weight of two samples was rather equal in the first day. After that, the loss weight of 50/10 sample was little smaller than that of $60 / 0$ sample. If the test was prolonged, the difference was greater. The loss weight of 50/10 and 60/0 samples after 8 test days was 1.89 and $2.09 \%$, respectively. That means, the presence of ESO in PVC formulation had a positive effect on the decrease in migration and volatilization of additives.

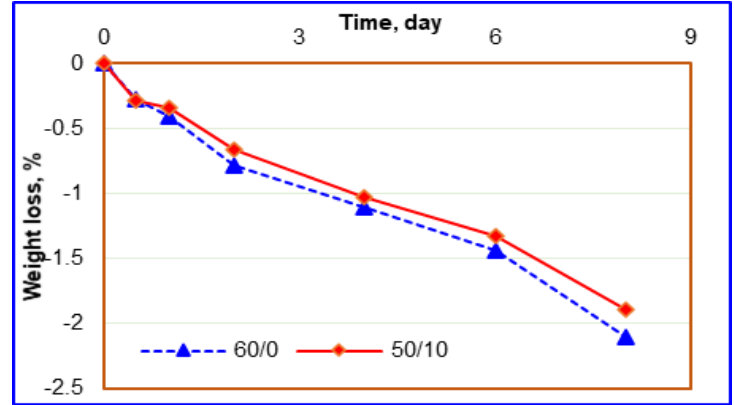

Fig. 5. The effect of ESO on migration and volatilization of PVC

\subsection{The effect of ESO on thermal property}
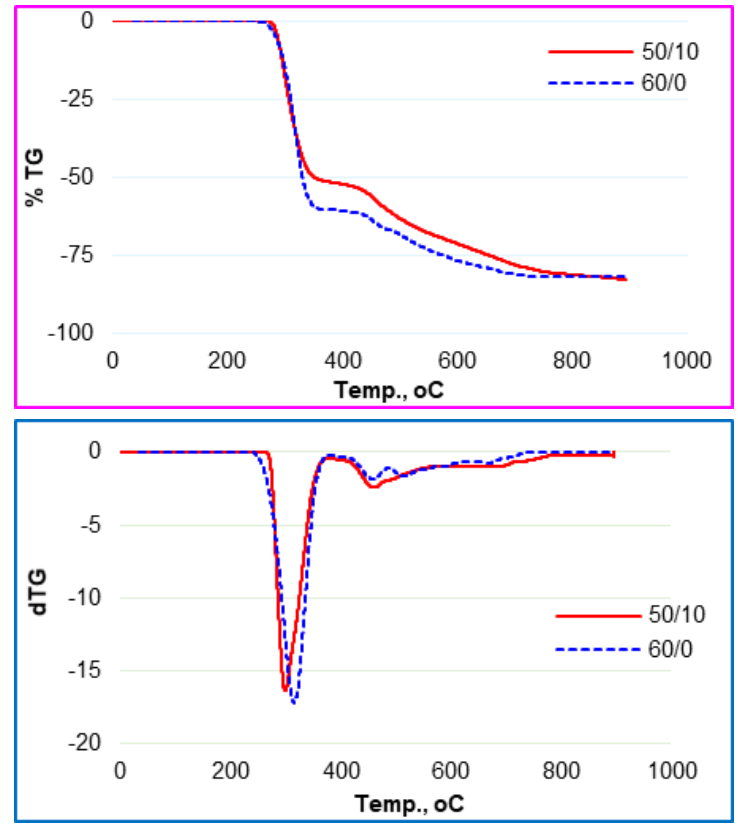

Fig. 6. TG (a) and dTG (b) thermograms of $60 / 10$ and $50 / 10$ samples

The decomposition curve behavior of two samples was rather similar and both took place in two stages. This was shown very clearly on the dTG curves (Fig.6b). In the first stage, the 60/0 sample began to disintegrate at $232{ }^{\circ} \mathrm{C}$ while it increased to $270{ }^{\circ} \mathrm{C}$ if $10 \mathrm{php}$ DOP in PVC formulation was replaced by ESO. However, the maximum degradation temperature of 50/10 sample was $298{ }^{\circ} \mathrm{C}$ 
and $17^{\circ} \mathrm{C}$ lower than that of $60 / 0$ sample in first stage and about $455^{\circ} \mathrm{C}$ in the second stage. The weight loss of first stage of $60 / 10$ sample was $60.89 \%$ and it became $51.15 \%$ as 10 php ESO substituted for DOP in $50 / 10$ sample. The weight loss at $600{ }^{\circ} \mathrm{C}$ of $50 / 10$ sample was $71.1 \%$ and $5.39 \%$ lower than that of $60 / 10$ sample. That means, the presence of ESO has improved the thermal property of PVC.

\section{Conclusions}

By replacing the $10 \mathrm{php}$ DOP plasticizer with ESO, a slight increase in tensile properties was observed. A variety of media were used to study the leaching property of PVC and the results showed that the presence of $10 \mathrm{php}$ ESO as a secondary plasticizer improved the leaching characteristic. The hardness of two samples became smaller after soaking in water, $30 \mathrm{wt} . \%$ acetic and $10 \mathrm{wt} . \% \mathrm{KOH}$ solution and much bigger in other media. The shore A hardness of 50/10 sample increased by $12 \%$ while sample $60 / 0$ was blistered and became very hard. The morphology of fractured surface of the samples after soaking in nhexane has clearly demonstrated this result. The replacing $10 \mathrm{php}$ DOP by ESO has also improved remarkably migration characteristic, thermal properties, and movement and volatilization in hot air. That means, ESO could be used as a secondary plasticizer in PVC formulation.

\section{Acknowledgements.}

Authors thank Mr. Nguyen Tien Thanh for his assistant.

\section{References}

[1]. B. L. Shah, V. V. Shertukde. Effect of plasticizers on mechanical, electrical, permanence, and thermal properties of poly(vinyl chloride). J. Appl. Polym. Sci. 90 (12), pp. 3278-3284, 2003. https://doi.org/10.1002/app.13049

[2]. T. Liu, P. Jiang, H. Liu, M. Li, Y. Dong, R. Wang, Y. Wang. Performance testing of a green plasticizer based on lactic acid for PVC. Polym. Test. 61, pp. 205-213, 2017.

[3]. S. Al-Malaika, F. Axtell, R. Rothon, M. Gilbert. Additives for Plastics, in: M. Gillbert (Ed.), Brydson's Plastics Materials, 8th ed., ButterworthHeinemann, Oxford, UK (2017) 127-168

[4]. J. Frados. Plastics engineering handbook, of the Society of the Plastics Industry, 4th ed., Van Nostrand Reinhold, New York, USA, 1976.

[5]. L. Krauskopf. Monomeric plasticizers, in: E. J. Wickson (Ed.). Handbook of polyvinyl chloride formulating, Wiley, New York, USA (1993) 216-219.

[6]. H. B. Pyeon, J. E. Park, D. H. Suh. Non-phthalate plasticizer from camphor for flexible PVC with a wide range of available temperature. Polym. Test. 63, pp. 375-381, 2017.

https://doi.org/10.1016/j.polymertesting.2017.08.029
[7]. H. Hosney, B. Nadiem, I. Ashour, I. Mustafa, A. ElShibiny. Epoxidized vegetable oil and bio-based materials as PVC plasticizer. J. Appl. Polym. Sci. 135 (20), 46270 (12pages), 2018. https://doi.org/10.1002/app.46270

[8]. O. Fenollar, D. Garcia-Sanoguera, L. SanchezNacher, J. Lopez, R. Balart. Effect of the epoxidized linseed oil concentration as natural plasticizer in vinyl plastisols. J. Mater. Sci. 45, pp. 4406-4413, 2010. https://doi:10.1007/s10853-010-4520-6

[9]. M. P. Arrieta, M. D. Samper, M. Jiménez-López, M. Aldas, J. López. Combined effect of linseed oil and gum rosin as natural additives for PVC. Ind. Crops Prod. 99, pp. 196-204, 2017.

https://doi.org/10.1016/j.indcrop.2017.02.009

[10]. R. Joseph, K. N. Madhusoodhanan, R. Alex, S. Varghese, K. E. George, B. Kuriakose. Studies on epoxidised rubber seed oil as secondary plasticiser/stabiliser for polyvinyl chloride. Plast. Rubber Compos. 3(5), pp. 217-222, 2004. https://doi.org/10.1179/146580104225020974

[11]. D. Balkose, T. O. Egbuchunam, F. E. Okieimen. Formulation and properties evaluation of PVC/(Dioctyl Phthalate)/(Epoxidized Rubber Seed Oil) plastigels. J. Vinyl Addit. Technol. 14(2), pp. 6572,2008 .

https://doi.org/10.1002/vnl.20142

[12]. P. Karmalm, T. Hjertberg, A. Jansson, R. Dahl, K. Ankner. Network formation by epoxidized soybean oil in plastisol poly (vinyl choride), Polym. Degrad. Stabil. 94, pp. 1986-1990, 2009.

https://doi.org/10.1016/j.polymdegradstab.2009.07.029

[13]. P. Karmalm, T. Hjertberg, A. Jansson, R. Dahl. Thermal stability of poly (vinyl chloride) with epoxidized soybean oil as primary plasticizer. Polym. Degrad. Stabil. 94, pp. 2275-2281, 2009.

https://doi.org/10.1016/j.polymdegradstab.2009.07.019

[14]. C. Bueno-Ferrer, M.C. Garrigós, A. Jimémez. Characterization and thermal stability of poly(vinyl chloride) plasticized with epoxidized soybean oil for food packaging. Polym. Degrad. Stabil. 95, pp. 22072212,2010

https://doi.org/10.1016/j.polymdegradstab.2010.01.027

[15]. Nguyen Duy Toan, Tran Thi Thanh Van, Đo Quang Tham, Nguyen Vu Giang, Nguyen Thuy Chinh, Thai Hoang. Fabrication and property investigation of composite materials PVC/a mixture of black coal and denatured fly ash. Journal of Chemistry 55 (1), pp. 8690, 2017.

[16]. Jie Chen, Xiaoying, Yigang Wang, Jinrui Huang, Ke $\mathrm{Li}$, Xiaoan Nie, Jianchun Jiang. Epoxidized dimeric acid methyl ester derived from rubber seed oil and its application as secondary plasticizer. J. Appl. Polym. Sci. 133(34), pp. 43668, 2016. https://doi.org/10.1002/app.43668

[17]. Nguyen Thi Thuy, Vu Minh Duc. The epoxidized linseed oil as a secondary plasticizer in PVC processing. Vietnam J. Chem. 58 (4), pp. 533-538, 2020.

https://doi.org/10.1002/vjch.202000023 